\title{
Cation Depletion by the Sodium Pump in Red Cells with Pathologic Cation Leaks Sickle Cells and Xerocytes
}

Clinton H. Joiner, Orah S. Platt, and Samuel E. Lux IV

Division of Perinatal Medicine, Department of Pediatrics, University of Alabama School of Medicine,

Birmingham, Alabama 35294; Division of Hematology/Oncology,

Department of Pediatrics, Harvard Medical School and The Children's Hospital, Boston, Massachusetts 02116

\begin{abstract}
The mechanism by which sickle cells and xerocytic red cells become depleted of cations in vivo has not been identified previously. Both types of cells exhibit elevated permeabilities to sodium and potassium, in the case of sickle cells, when deoxygenated. The ouabain-insensitive fluxes of sodium and potassium were equivalent, however, in both cell types under these conditions. When incubated 18 hours in vitro, sickle cells lost cations but only when deoxygenated. This cation depletion was blocked by ouabain, removal of external potassium, or pretreatment with 4,4'-diisothiocyanostilbene-2,2'-disulfonate, which blocks the increase in cation permeability induced by deoxygenation. The loss of cation exhibited by oxygenated xerocytes similarly incubated was also blocked by ouabain. These data support the hypothesis that the elevated "passive" cation fluxes of xerocytes and deoxygenated sickle cells are not directly responsible for cation depletion of these cells; rather, these pathologic leaks interact with the sodium pump to produce a net loss of cellular cation.
\end{abstract}

\section{Introduction}

Cellular dehydration is a feature of several red blood cell disorders of diverse etiologies. Two of these are sickle cell disease, an autosomal recessive hemoglobinopathy, and hereditary xerocytosis, an autosomal dominant disorder, characterized by compensated hemolytic anemia, reduced osmotic fragility, and red cell morphology showing target cells and/or stomatocytes. Sickle cell density profiles (which reflect cellular hydration) are markedly heterogeneous, with certain cells showing striking reductions in cation and water content $(1,2)$. Red cells in xerocytosis also exhibit reduced cation and water content and elevated hemoglobin concentration (3-6).

In erythrocytes, hemoglobin concentration is a major determinant of cell deformability $(3,7)$; both sickle cells and xerocytes have reduced deformability, which can be improved by rehy-

Preliminary reports of this work were presented at the Annual Meeting of the American Society for Clinical Investigation, Washington, DC, 69 May 1984 (1984. Clin. Res. 32:497a) and at the Southern Society for Pediatric Research, New Orleans, LA, 10-14 February 1985 (1985. Clin. Res. 32:890a.).

Address reprint requests to Dr. Clinton H. Joiner, University Hospital, Birmingham, AL 35294.

Received for publication 31 March 1986.

J. Clin. Invest.

(c) The American Society for Clinical Investigation, Inc.

$0021-9738 / 86 / 12 / 1487 / 10 \$ 1.00$

Volume 78, December 1986, 1487-1496 dration in vitro $(3,8,9)$. The concept of deformability as a major determinant of red cell survival is supported by the observations that dehydrated populations of oxygenated sickle cells exhibit abnormal rheologic behavior, and increased sensitivity to physiologic shear stress $(7,9-11)$. Shear sensitivity was shown to improve with rehydration (9); the effects of rehydration on rheologic behavior have not been tested. In addition, because polymerization rates of deoxygenated hemoglobin $S$ are highly sensitive to hemoglobin concentration (12), even small increments of cation and water loss enhance the tendency of sickle cells to sickle upon deoxygenation $(13,14)$. Cellular dehydration, then, seems to play a significant role in the pathophysiology of both sickle cell anemia and xerocytosis.

The mechanism by which these cells become dehydrated has not yet been elucidated. Dehydration follows pari passu the loss of cation from red cells, and abnormal cation permeability has been demonstrated in both types of cells. In xerocytes, this transport abnormality is presumably the result of a primary membrane permeability defect $(3,5)$. Sickle cells exhibit a striking, reversible increase in monovalent cation permeability when deoxygenated $(15,16)$. Both cell types are more potassium depleted than sodium loaded, and it has been assumed that the membrane permeability to potassium exceeds that for sodium. The available data on net ion movements in sickle cells and xerocytes suggest, however, that net sodium and potassium fluxes are balanced (15-18), although the flux of sodium stimulated by deoxygenation of sickle cells has not been quantitatively compared to that of potassium. The basic permeability defects of sickle cells and xerocytes thus have not been thoroughly characterized, and apparently do not explain the cation depletion of these cells. In addition, the interaction of these cation leaks with other transport systems has not been explored.

Clark et al. $(19,20)$, assuming that unbalanced $\mathrm{K}$ loss is primarily responsible for cation depletion of sickle cells, have suggested that dehydration of sickle cells (which become sodium loaded by the increased sodium influx occurring with deoxygenation) might be accelerated by sodium pump activity because of the pump's coupling ratio of $3 \mathrm{Na}_{\text {out }}: 2 \mathrm{~K}_{\mathrm{in}}$. They have shown the capacity of the pump to lower cation content in normal red cells loaded with sodium by nystatin treatment (19). The interaction of the sodium pump and deoxy cation fluxes to produce cation depletion in sickle cells has not yet been demonstrated experimentally, however, and the role of the pump in cation loss from xerocytes has not been explored.

We report that the net sodium and potassium fluxes in the red cells of two patients with xerocytosis are equal and that the increase in cation permeability seen in deoxygenated sickle cells also results in balanced sodium and potassium movements. We present data showing that net cation loss occurs in both types of cells as a result of the activity of the sodium pump in response to increased sodium influx. 


\section{Methods}

Blood. Sickle cells were obtained from otherwise healthy patients homozygous for hemoglobin $S$ by venipuncture into tubes containing either EDTA or heparin. Blood from xerocytosis patients was drawn into EDTA and transported on ice to the laboratory. All blood was used within $3 \mathrm{~h}$ of sampling. Controls were normal volunteers. Mean corpuscular hemoglobin concentration (MCHC) was calculated from the optical density at $540 \mathrm{~nm}$ of hemoglobin from lysed cells and the hematocrit, measured on oxygenated cells in whole blood spun at $13,000 \mathrm{~g}$ for $5 \mathrm{~min}$. Cells were washed three times in appropriate media and resuspended at $2 \%$ hematocrit $(0.5 \%$ for $\mathrm{K}$-free incubations).

Patients. Two siblings with autosomal dominant hereditary xerocytosis were studied. Both had well-compensated hemolysis with consistently normal hematocrits (39-44\%) and elevated reticulocyte counts (15-20\%). Mean corpuscular volumes were elevated and ranged between 105 and $108 \mu \mathrm{m}^{3}$; MCHC was 35.3 to $41.1 \mathrm{~g} / 100 \mathrm{ml}$ (normal = 33.534.0 ), reflecting the reduced water content of these cells. Osmotic fragility curves demonstrated osmotic resistance; $50 \%$ hemolysis of patient cells occurred at 0.38 and $0.45 \% \mathrm{NaCl}$ (control $=0.55 \pm 0.05 \% \mathrm{NaCl}$ ). Density profiles were determined by centrifugation through phthalate ester mixtures, as described by Danon (21). Both patients showed a marked shift to higher densities, with a median buoyant density of $1.112-1.114 \mathrm{~g} / \mathrm{ml}$ as compared to $1.098-1.010 \mathrm{~g} / \mathrm{ml}$ for normal cells. Sickle cells have also been shown by this technique to have a high proportion of dense cells (1).

The individuals with sickle cell anemia who were studied all had chronic hemolytic anemia without microcytosis, and hemoglobin electrophoresis showing a predominance of hemoglobin $\mathrm{S}$, no hemoglobin $A_{1}$, normal levels of hemoglobin $A_{2}$, and $<15 \%$ fetal hemoglobin. Patients had not received transfusions for at least 4 mo prior to sampling.

Incubation media. Phosphate-buffered saline (PBS) contained: 110 $\mathrm{mM} \mathrm{NaCl}, 20 \mathrm{mM} \mathrm{Na}_{2} \mathrm{HPO}_{4}$ (pH 7.45), $15 \mathrm{mM}$ tetramethylammonium$\mathrm{Cl}, 0.1 \mathrm{mM}$ EDTA, $10 \mathrm{mM}$ glucose. When potassium was added (PBS5K), $5 \mathrm{mM} \mathrm{KCl}$ substituted for an equivalent amount of tetramethylammonium-Cl. Glycylglycine-buffered saline (GBS) contained: $130 \mathrm{mM} \mathrm{NaCl}, 20 \mathrm{mM}$ glycylglycine (pH 7.45, titrated with $\mathrm{NaOH}$ ), 5 $\mathrm{mM} \mathrm{KCl}, 1 \mathrm{mM} \mathrm{MgCl} 2,10 \mathrm{mM}$ glucose, $1 \mathrm{mg} / \mathrm{ml}$ bovine serum albumin. Media osmolality was 285-295 (Osmette II, Advanced Instruments, Waltham, MA). Ouabain was obtained from Sigma Chemical Co. (St. Louis, MO) and, when present, was added as $10 \mathrm{mM}$ stock solution in water to give $0.1 \mathrm{mM}$ final concentration; an equal volume of water was added to controls. All chemicals were reagent grade; water was predeionized and doubly distilled.

Nystatin treatment. Normal cells were treated with nystatin (Sigma Chemical Co.) by methods previously described (22). Briefly, washed cells were incubated at $2 \%$ hematocrit $20 \mathrm{~min}$ at $0^{\circ} \mathrm{C}$ in phosphatebuffered medium containing the desired sodium and potassium concentrations plus $25 \mathrm{mM}$ sucrose and $30 \mu \mathrm{g} / \mathrm{ml}$ nystatin. Washing was carried out at $22^{\circ} \mathrm{C}$ in the same medium (minus drug) plus $1 \mathrm{mg} / \mathrm{ml}$ bovine serum albumin. After seven such washes, cells were washed three times in the appropriate incubation medium.

Net cation fluxes. Cells were incubated in PBS with $0.1 \mathrm{mM}$ ouabain at $37^{\circ} \mathrm{C}$; for sickle cell experiments, one of a pair of samples was deoxygenated. Deoxygenation was carried out in tightly capped flasks by alternate vacuum and $\mathrm{N}_{2}$ bubbling, and $\sim 10$ min was required for $\mathrm{PO}_{2}$ to stabilize at 10-20 torr (measured on ABL III, Radiometer Corp., Copenhagen, Denmark). Paired flasks were equilibrated with air. Sampling from sealed deoxygenated flasks was accomplished after deoxygenation and without reoxygenation of the remaining suspension by means of ports fitted with stopcocks. Samples (10-30 $\mu$ l cells) were taken in triplicate and handled as described elsewhere (23). Hemolysates were

1. Abbreviations used in this paper: DIDS, 4,4'-diisothiocyanostilbene2,2'-disulfonate; DNDS, 4,4'-dinitrostilbene-2,2'-disulfonate; GBS, glycylglycine-buffered saline; MCHC, mean corpuscular hemoglobin concentration; PBS5K, PBS with $5 \mathrm{mM} \mathrm{KCl}$. analyzed for sodium and potassium by flame emission spectroscopy on an atomic absorption spectrophotometer (model 372, Perkin-Elmer Corp., Norwalk, CT) and for hemoglobin as described above. Sodium uptake and potassium loss were linear with time over 2-4-h incubation periods. Accordingly, most of the net fluxes reported were calculated from the difference in cation contents between samples at 0 and 2 or 3 h. For sickle cells, the deoxy fluxes were calculated as the difference in flux rates in deoxygenated and oxygenated cells. Net cation fluxes were chosen over isotopic measurements to avoid problems with exchange diffusion, especially $\mathrm{Na}: \mathrm{Na}$ exchange. Because external potassium was very low and internal sodium usually remained $<30 \mathrm{mM} /$ /iter cells, net potassium efflux and sodium influx in the absence of sodium pumping approximate unidirectional ion movements.

Long-term incubations. Cells were prepared as above and suspended in PBS (with or without K) or GBS containing penicillin $\mathrm{G}(100 \mu \mathrm{g} / \mathrm{ml})$ and gentamicin $(10 \mu \mathrm{g} / \mathrm{ml})$. Initial samples were taken after deoxygenation, and the cells incubated at $37^{\circ} \mathrm{C}$ in a reciprocating water bath at $100 \mathrm{cycles} / \mathrm{min}$. After $8-10 \mathrm{~h}$, cells were reoxygenated, spun down, and resuspended in fresh media; previously deoxygenated samples were deoxygenated again. Final samples were taken at $18 \mathrm{~h}$. Immediately before cation samples were taken, deoxygenated cells were reoxygenated. The $\mathrm{pH}$ of media after $9 \mathrm{~h}$ incubation was 7.3-7.4. Total cations were measured and ion content expressed as milliequivalents per kilogram of hemoglobin. The percent change in ion content was calculated as the difference between initial and final cation content divided by initial content $(\times 100)$.

\section{Results}

Deoxy sodium and potassium fluxes in sickle cells are balanced. Net sodium and potassium fluxes stimulated by deoxygenation of ouabain-treated sickle cells (deoxy fluxes) were measured in 34 experiments on 25 individuals. In Fig. 1 deoxy potassium efflux is plotted versus the paired deoxy sodium influx for a given experiment. These data illustrate the broad range of deoxy sodium and potassium fluxes seen among individual patients and also demonstrate that the relationship between deoxy sodium influx and deoxy potassium efflux remains unchanged despite this variability. The slope of the line obtained by least-squares analysis (dotted line on figure) is $0.82 \pm 0.10$, which is not significantly different from 1 . An alternative analysis is to compute the ratio of deoxy potassium efflux to deoxy sodium influx for

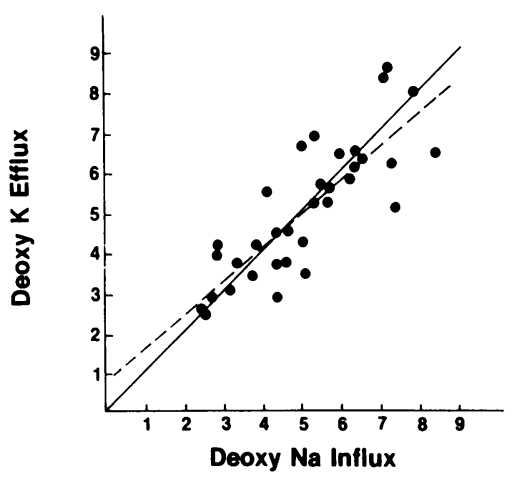

Figure 1. Deoxy cation fluxes in sickle cells. Net sodium and potassium fluxes (in millimoles per liter cell per hour) were measured as described in Methods. The difference between the fluxes in nitrogen and air defines the deoxy flux. Data are from 34 experiments in 25 individuals. The solid line is the line of identity and the dotted line is the least-squares regression line (slope $=0.82, \pm 0.10$, standard error of estimate, $r=0.820$ ). Statistical analysis (Student's $t$ test) indicated that the two slopes were indistinguishable $(P=0.086$ for difference in slopes). 
each measurement. The mean of this ratio for the 34 measurements in Fig. 1 was $1.006 \pm 0.034$ (SEM). Thus, it is clear that deoxy potassium efflux in sickle cells is balanced by an equivalent deoxy sodium influx, independent of the magnitude of the fluxes. These data indicate that deoxy cation fluxes alone cannot be responsible for cation depletion in sickle red cells. This conclusion is further supported by the long-term incubation experiments presented below.

Net sodium and potassium fluxes in xerocytes are balanced. Table I presents red cell cation data for two patients with xerocytosis and for comparison includes data from three other published studies on pathologic red cells that meet the criteria for xerocytosis (elevated MCHC, reduced cellular cations and/or water content, and resistant osmotic fragility) and on which net cation flux measurements were made. There is considerable variability in $\mathrm{Na}$ and $\mathrm{K}$ contents, as well as in net cation fluxes among these various patients. In fact, it should not be assumed that different kindreds with xerocytosis share a common basic defect; it is likely that a number of molecularly distinct membrane defects give rise to the clinical phenotype defined as xerocytosis. In one of our patients (A.C.), sodium and potassium fluxes were nearly balanced, while in the second (R.C.), sodium influx exceeded $\mathrm{K}$ efflux slightly. The rate of net potassium efflux did not exceed the net sodium influx rate in these patients or in the three other studies of xerocytic red cells. If permeability (p) is estimated by dividing the observed flux by the cation gradient as suggested by Glader et al. (5), sodium and potassium permeabilities in our patients remained approximately equivalent, although heterogeneity in this parameter among the reported cases is again evident. Therefore, although the increase (relative to normal cells) in potassium permeability is greater than the increase in sodium permeability (5), it is clearly not an unbalanced leak of potassium that leads to cation depletion of xerocytes. In other words, the passive fluxes of sodium and potassium are not singularly responsible for dehydration in these cells.

In order to examine the relative magnitudes in xerocytes of the known pathways for net potassium movements, the unidirectional uptake of rubidium was measured. In normal cells, potassium influx can be separated into three distinct pathways: pump (ouabain sensitive), sodium potassium cotransport (bumetanide sensitive, ouabain insensitive), and residual (ouabain and bumetanide insensitive). Residual fluxes approximate the permeability of the lipid bilayer, and there is very little potassium self-exchange under physiologic conditions (24). Measurements of ouabain-sensitive, bumetanide-sensitive, and ouabain- and bumetanide-insensitive rubidium uptake are presented in Table II for xerocytes and for six normal blood samples. Pump activity was clearly elevated in xerocytes, as has been reported for certain other pathologically leaky red cells, and which presumably relates to both the youth of these cells as well as their elevated cellular sodium $(25,26)$. Similarly, the cotransport influx rate in xerocytes exceeds that of normal cells (more than three standard deviations above the mean). Elevations in cotransport have been reported for other pathologic cells (27), although little data is available on the relationship between red cell age and cotransport activity. The most dramatic increase in cation permeability in xerocytes was in the component of rubidium influx insensitive to both ouabain and bumetanide; this residual rubidium uptake was some 10 times normal. This finding agrees qualitatively with the data on net potassium fluxes in these cells, but quantitative comparisons of permeability estimates based on net fluxes and unidirectional fluxes (Rb uptake) must be made with caution.

Regardless of the precise nature of the pathway mediating net cation movements in xerocytes and deoxygenated sickle cells, the balanced nature of the net sodium and potassium fluxes indicates that other mechanisms must be sought to explain cation depletion in these cells. We have investigated the effects of sodium pump compensation for high cation leaks in these cells.

Cation depletion of normal, sodium-loaded red blood cells requires the sodium pump. The capacity of the pump to extrude net cation in sodium loaded cells is crucial to the involvement of this system in cation depletion of cells with elevated membrane permeability. We designed experiments to confirm the data of Clark et al. (20) showing dehydration of normal cells loaded with sodium by exposure to nystatin, followed by extensive washing to remove the drug. Table III shows changes in cation content of normal cells incubated in PBS5K \pm ouabain. In both experiments presented, cells were treated with nystatin to give either low-sodium, high-potassium contents (comparable with control cells not treated with nystatin), or high sodium, where cellular sodium and potassium were approximately equal $(\sim 50$ meq/liter cells). Table III shows that high sodium cells incubated

Table I. Cation Transport Parameters in Xerocytes

\begin{tabular}{|c|c|c|c|c|c|c|c|}
\hline & \multicolumn{3}{|c|}{ Cation content } & \multicolumn{2}{|c|}{ Net cation fluxes } & \multicolumn{2}{|c|}{ Permeability $(\mathbf{p})^{*}$} \\
\hline & $\mathrm{Na}$ & $\mathbf{K}$ & $(\mathrm{Na}+\mathrm{K})$ & $\mathrm{Na}$ influx & $K$ efflux & $\mathrm{Na}$ & $\mathbf{K}$ \\
\hline & \multicolumn{3}{|c|}{ mmol/liter cells } & \multicolumn{4}{|c|}{ mmol/liter cells per $h$} \\
\hline \multicolumn{8}{|l|}{ This study } \\
\hline \multirow[t]{2}{*}{$\mathrm{AC}$} & 38.0 & 51.1 & 89.1 & 5.9 & $6.8 \ddagger$ & 0.077 & $0.077 \S$ \\
\hline & & & & 7.6 & 5.7 & & \\
\hline $\mathbf{R C}$ & 34.6 & 51.1 & 85.7 & $7.8(2.0)$ & $5.8(0.8)^{\|}$ & 0.085 & 0.072 \\
\hline Wiley et al. (6) & 10 & 86 & 97.0 & 4.0 & 3.3 & 0.030 & 0.026 \\
\hline \multirow[t]{2}{*}{ Glader et al. (5) } & 19 & 59 & 78 & 4.9 & 4.9 & 0.043 & 0.045 \\
\hline & & & & 4.3 & 3.4 & 0.034 & 0.036 \\
\hline Platt et al. (4) & 14 & 77 & 91 & 4.1 & 3.1 & 0.032 & 0.025 \\
\hline
\end{tabular}

\footnotetext{
* Permeability is estimated as the net flux rate divided by the cation gradient across the membrane; initial cation contents were used to estimate cation gradients. ‡ Data from two separate experiments. § Calculated from the average fluxes from two determinations. "Means (standard deviations) from five measurements.
} 
Table II. Cation Transport Pathways in Xerocytes

\begin{tabular}{llll}
\hline & \multicolumn{3}{l}{ Unidirectional rubidium influx* } \\
\cline { 2 - 4 } Patients & Pump $\neq$ & Cotransport§ & Residual" \\
\hline AC & 4.31 & 1.03 & 1.44 \\
RC & 3.74 & 1.01 & 1.03 \\
Controls & $1.64 \pm 0.24$ & $0.55 \pm 0.22$ & $0.10 \pm 0.02$ \\
\hline
\end{tabular}

Cells were incubated at $37^{\circ} \mathrm{C}$ in PBS (K free) with $5.5 \mathrm{mM} \mathrm{Rb}$. Ouabain when present was $0.1 \mathrm{mM}$ and bumetanide, $0.02 \mathrm{mM}$ (gift of Hoffmann-La Roche, Inc., Nutley, NJ). Samples were taken at 0 and $1 \mathrm{~h}$ and processed as for other cation measurements, measuring $\mathrm{Rb}$ by flame emission.

* Results are expressed as mmol/liter cell per $h$.

$\ddagger$ Ouabain-sensitive $\mathbf{R b}$ influx.

$\S$ Bumetanide-sensitive (ouabain-insensitive) $\mathbf{R b}$ influx.

"Ouabain- and bumetanide-insensitive $\mathbf{R b}$ influx.

II Means \pm SD in six normal individuals.

without ouabain lowered sodium levels to near normal, but without accumulating sufficient potassium to reach control potassium levels. These cells (high sodium with active pumps) thus had reduced cation contents after $18 \mathrm{~h}$ incubation in vitro: $22 \%$ lower in experiment $A$ and $18 \%$ in experiment $B$. When high-sodium cells were treated with ouabain, the cation loss was blocked, implicating the sodium pump in this process. The requirement for sodium loading is demonstrated by the stability of cation contents in control cells and low-sodium nystatintreated cells. These data confirm the findings of Clark et al. (20), and indicate that the sodium pump can mediate net cation extrusion in sodium loaded cells. The absence of consistent changes in cation content in ouabain-treated cells suggests that the sodium potassium cotransport system, which is ouabain insensitive, does not mediate net change in total cellular cation content under these conditions.

Cation depletion of sickle cells in vitro requires the sodium pump and deoxy cation fluxes. In order to explore the interaction of deoxy cation fluxes and the sodium pump in sickle cells, we designed experiments to demonstrate loss of cations in sickle cells in vitro under deoxy conditions, and to evaluate the role of active transport in this process by blocking the pump by two independent methods: ouabain and removal of potassium from the incubation media.

In the first series of experiments, sickle cells were incubated in PBS5K for $18 \mathrm{~h}$ under four conditions: oxygenated or deoxygenated, touabain. Table IV presents data from four such experiments. There was considerable variability among the patients as to initial and final cellular cation contents. Consequently, it is necessary to focus on changes in cation content, normalized to the initial cation levels (percent change) for the various incubation conditions. Cells incubated with ouabain generally

Table III. Cation Depletion in Sodium-loaded Normal Cells

\begin{tabular}{|c|c|c|c|c|c|c|c|c|}
\hline & \multicolumn{8}{|c|}{ Cation content $(\mathrm{meq} / \mathrm{kg} \cdot \mathrm{Hb})$} \\
\hline & \multicolumn{3}{|l|}{ Initial } & \multirow[b]{2}{*}{ Ouabain } & \multicolumn{4}{|l|}{ Final } \\
\hline & $\mathrm{Na}$ & K & $(\mathrm{Na}+\mathrm{K})$ & & $\mathrm{Na}$ & $\mathbf{K}$ & $(\mathrm{Na}+\mathrm{K})$ & Percent change \\
\hline \multicolumn{9}{|l|}{ Experiment $\mathrm{A}$} \\
\hline \multirow[t]{3}{*}{ Control } & 20.0 & 303 & 323 & & & & & \\
\hline & & & & - & 26.3 & 277 & 304 & -6.9 \\
\hline & & & & + & 83.6 & 237 & 322 & -0.0 \\
\hline Nystatin treated & 28.6 & 391 & 420 & & & & & \\
\hline \multirow[t]{2}{*}{ Low $\mathrm{Na}$} & & & & - & 27.9 & 361 & 388 & -7.6 \\
\hline & & & & + & 94.3 & 307 & 403 & -4.0 \\
\hline Nystatin treated & 182 & 209 & 391 & & & & & \\
\hline \multirow[t]{2}{*}{ High Na } & & & & - & 34.0 & 269 & 304 & -22.0 \\
\hline & & & & + & 209 & 154 & 364 & -6.9 \\
\hline \multicolumn{9}{|l|}{ Experiment B } \\
\hline \multirow[t]{3}{*}{ Control } & 44.2 & 273 & 317 & & & & & \\
\hline & & & & - & 48.1 & 281 & 328 & +3.5 \\
\hline & & & & + & 120 & 216 & 334 & +5.3 \\
\hline Nystatin treated & 44.6 & 274 & 319 & & & & & \\
\hline \multirow[t]{2}{*}{ Low $\mathrm{Na}$} & & & & - & 65.1 & 279 & 343 & +7.5 \\
\hline & & & & + & 122 & 203 & 325 & +1.9 \\
\hline Nystatin treated & 160 & 151 & 311 & & & & & \\
\hline \multirow[t]{2}{*}{ High $\mathrm{Na}$} & & & & - & 61.2 & 194 & 255 & -18.0 \\
\hline & & & & + & 277 & 105 & 331 & +6.4 \\
\hline
\end{tabular}

Cells were treated with nystatin as described in Methods and then washed to remove drug. Control cells were handled similarly, but without nystatin treatment. In experiment A, nystatin-treated cells had $25 \%$ higher cation content (and therefore volume) than untreated cells; cells in experiment B were euvolemic. Incubation was at $37^{\circ} \mathrm{C}$ for $18 \mathrm{~h}$ in PBS plus $5 \mathrm{mM} \mathrm{K} \pm$ ouabain. Percent change compares final with initial $(\mathrm{Na}+\mathrm{K})$. Standard deviations for the triplicate cation determinations were omitted in this and the following tables for the sake of clarity, but ranged from 1 to $4 \%$ for both sodium and potassium. 
Table IV. 18-h Incubation of Sickle Cells: Effects of Deoxygenation and Ouabain

\begin{tabular}{|c|c|c|c|c|c|c|c|c|}
\hline & \multicolumn{8}{|c|}{ Cation content $(\mathrm{meq} / \mathrm{kg} \cdot \mathrm{Hb})$} \\
\hline & \multicolumn{3}{|l|}{ Initial } & \multirow[b]{2}{*}{ Condition } & \multicolumn{4}{|l|}{ Final } \\
\hline & $\mathrm{Na}$ & $\mathbf{K}$ & $(\mathrm{Na}+\mathrm{K})$ & & $\mathrm{Na}$ & $\mathbf{K}$ & $(\mathrm{Na}+\mathrm{K})$ & Percent change \\
\hline \multirow[t]{4}{*}{ Experiment 1} & 70.2 & 226 & 296 & $\mathrm{~A} \mathrm{O}_{2}$ & 61.8 & 228 & 290 & -2.0 \\
\hline & & & & B $\mathrm{N}_{2}$ & 80.4 & 177 & 257 & -12.9 \\
\hline & & & & $\mathrm{C} \mathrm{O}_{2}+$ ouabain & 105 & 200 & 305 & +3.4 \\
\hline & & & & $\mathrm{D} \mathrm{N}_{2}+$ ouabain & 153 & 157 & 310 & +5.1 \\
\hline \multirow[t]{4}{*}{ Experiment 2} & 76.4 & 326 & 402 & $\mathrm{~A} \mathrm{O}_{2}$ & 113 & 298 & 411 & +2.2 \\
\hline & & & & B N $\mathrm{N}_{2}$ & 117 & 253 & 370 & -8.6 \\
\hline & & & & $\mathrm{C} \mathrm{O}_{2}+$ ouabain & 186 & 234 & 421 & +2.5 \\
\hline & & & & $\mathrm{D} \mathrm{N}_{2}+$ ouabain & 371 & 95 & 465 & +15.7 \\
\hline \multirow[t]{4}{*}{ Experiment 3} & 100 & 280 & 380 & $\mathrm{~A} \mathrm{O}_{2}$ & 105 & 292 & 397 & +4.7 \\
\hline & & & & B N & 141 & 182 & 323 & -15.0 \\
\hline & & & & $\mathrm{C} \mathrm{O}_{2}+$ ouabain & 195 & 216 & 411 & +7.4 \\
\hline & & & & $\mathrm{D} \mathrm{N}_{2}+$ ouabain & 296 & 98.2 & 394 & +3.7 \\
\hline \multirow[t]{4}{*}{ Experiment 4} & 59.1 & 296 & 355 & $\mathrm{AO}_{2}$ & 58.8 & 286 & 345 & -2.8 \\
\hline & & & & B N $\mathrm{N}_{2}$ & 188 & 130 & 318 & -10.4 \\
\hline & & & & $\mathrm{CO}_{2}+$ ouabain & 103 & 237 & 340 & -4.2 \\
\hline & & & & $\mathrm{D} \mathrm{N}_{2}+$ ouabain & 300 & 64.8 & 365 & +2.8 \\
\hline
\end{tabular}

Cells were incubated in PBS $5 \mathrm{~K} \pm$ ouabain and equilibrated with air or nitrogen as described in Methods. Percent change compares final (Na $+\mathrm{K}$ ) to initial $(\mathrm{Na}+\mathrm{K})$. Standard deviations for triplicate measurements range from 1 to $4 \%$.

gained cations whether oxygenated (condition $\mathrm{C}$ ) or deoxygenated (condition D). This confirms the conclusion drawn from the short-term net flux studies that "passive" cation fluxes do not result in cation depletion in sickle cells even in the deoxygenated state. These ouabain-insensitive fluxes represent the vectoral sum of all other transport pathways except the sodium pump. If the sodium potassium cotransport system mediated net outward movement of cation in sickle cells, loss of cation in ouabain-treated cells would be expected. Oxygenated cells with active sodium pumps (no ouabain, condition A) had virtually constant cellular sodium and potassium (and therefore total cation) contents. Deoxygenated cells with active pumps (condition B), however, showed a consistent fall in total cation contents after $18 \mathrm{~h}$ incubation. This is illustrated graphically in Fig. 2, where the mean values for changes in total cations for the four experiments in Table IV are depicted for each incubation condition. Statistical analysis of the differences between oxy-

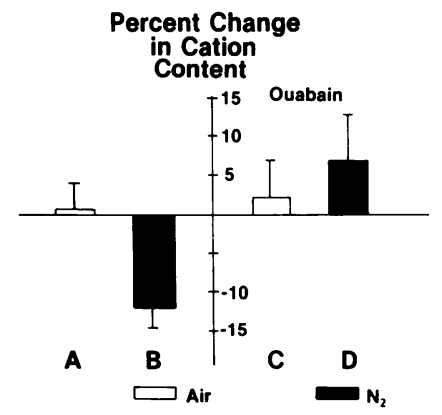

Figure 2. Cation changes in sickle cells incubated $18 \mathrm{~h}$ in PBS5K: effects of deoxygenation and ouabain. The changes for each condition described in Table IV were averaged for the four experiments presented. Histograms represent the means and error bars the standard deviations. Statistical comparisons were by $t$ test (two-tailed, unpaired). For condition $A$ vs. condition $B, P$ $<0.0016$; for $B$ vs. $D, P$ $<0.0014$. genated and deoxygenated cells without ouabain ( $A$ vs. $B$ ) and deoxygenated cells \pm ouabain $(B$ vs. $D$ ) yield $P$ values $<0.0016$ and 0.0014 , respectively. Both deoxygenation and the sodium pump thus are required for cation depletion of sickle cells.

In the experiments depicted in Table IV and Fig. 2, MCHC was also measured before and after incubation. Because hemoglobin concentration is inversely related to cell water (assuming constant hemoglobin content), $\mathrm{MCHC}$ should increase as cation content decreases. The percent changes in MCHC for the four experiments with sickle cells presented above are depicted in Fig. 3. Deoxygenated cells with active pumps (condition $B$ ) showed a $12.6 \%$ increase in $\mathrm{MCHC}$, which was significantly different from oxygenated cells (condition $A$ ) and ouabain-treated deoxygenated cells (condition $D$ ). MCHC measurements thus reflected the changes in ion content seen in deoxygenated sickle cells and confirmed the effect of pump blockade on these changes. These findings are consistent with those of Izuma et al., who reported an increase in MCHC in deoxygenated sickle cells incubated in vitro, which was blocked by ouabain (28). Unfortunately, incubation conditions were not fully specified in that

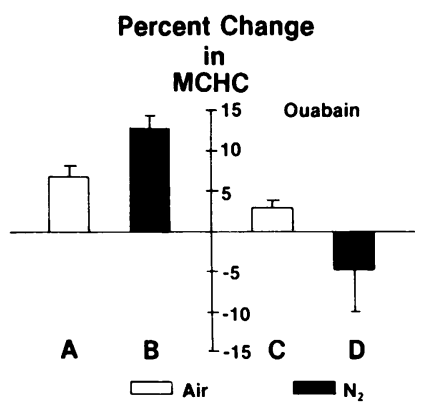

Figure 3. Changes in MCHC of sickle cells incubated $18 \mathrm{~h}$ in PBS5K: effect of ouabain. Data are from the experiments presented in Table IV and Fig. 2. Means of MCHC percentage changes in determinations for the various conditions are presented along with standard deviations. Statistical comparisons ( $t$ test): $A$ vs. $B, P<0.002$; $B$ vs. $D, P<0.015$. 
report, and no direct measurements of cation contents were made, so direct comparison to the present study cannot be made.

Normal red cells, incubated under similar conditions, showed very little change in total cation content, and no effect of deoxygenation was noted, as shown in Table V. Differences among the different incubation conditions for normal cells were not statistically significant. The difference between normal and sickle cells incubated under deoxygenated conditions without ouabain (condition $B$, using data on sickle cells from Table IV and three additional experiments summarized in Fig. 4) was significant at $P<0.006$.

To explore further the role of the sodium pump in cation depletion of sickle cells, the effect of pump blockade by removal of external potassium $\left(K_{0}\right)$ was tested. Cells were incubated in $\mathrm{PBS} \pm 5 \mathrm{mM} K_{0}$ under oxygenated and deoxygenated conditions. The resultant changes in cation contents after $18 \mathrm{~h}$ are shown in Fig. 4 as the means $( \pm \mathrm{SD})$ of three experiments. Deoxygenated sickle cells incubated with active pumps ( $5 \mathrm{mM} K_{0}$, condition $B$ ) showed cation loss of $10 \%$ compared to the stable cation content of oxygenated cells in $5 \mathrm{mM} \mathrm{K}_{0}$ (condition $A$ ) while deoxygenated cells in " 0 " $\mathrm{K}$ media (condition $F$ ) showed no consistent cation depletion. The difference between oxygenated and deoxygenated cells ( $A$ vs. $B$ ) was statistically significant at a level of $P<0.001$, and at $P<0.028$ for the comparison between deoxygenated cells with and without $\mathrm{K}_{0}$ ( $B$ vs. $F$ ).

We recently reported that deoxy cation fluxes are blocked by inhibitors of anion transport, including 4,4'-diisothiocyanostilbene-2,2'-disulfonate (DIDS) and 4,4'-dinitrostilbene-2,2'-disulfonate (DNDS) (29). The irreversible inhibition of deoxy cation fluxes produced by DIDS allows a pharmacologic test of the role of these fluxes in cation depletion of sickle cells, analogous to the use of ouabain for the sodium pump. Cells were pretreated with DIDS $(10 \mu \mathrm{M})$ at $37^{\circ} \mathrm{C}$ for $20 \mathrm{~min}$, then washed three times to remove unbound drug. Such conditions were found in preliminary experiments to inhibit $70-90 \%$ of the increase in net cation fluxes stimulated by deoxygenation of sickle cells, although such measurements were not performed on the cells in these experiments due to limitations in sample size. Control cells were similarly preincubated without DIDS. After washing, cells were suspended in PBS5K under oxygenated and deoxygenated conditions and cations measured at the beginning and end of $18 \mathrm{~h}$ incubation. The percent changes in cation content are depicted in Fig. 5 as the means of four experiments. As before, control deoxygenated sickle cells (condition $B$ ) showed significant cation depletion. Deoxygenated cells pretreated with DIDS (condition $H$ ) had significantly less cation loss $(P<0.022, B$ vs. $H)$, although under oxygenated circumstances, DIDS treatment had no effect on cation content (condition G). Pretreatment with DIDS had

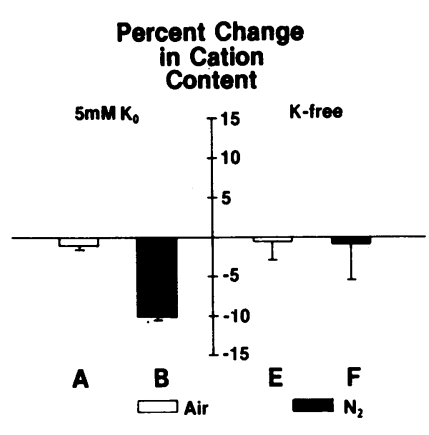

Figure 4. Cation changes in sickle cells incubated $18 \mathrm{~h}$ in PBS: effect of external $\mathrm{K}$ removal. Data are means for each condition from three experiments. Cells were incubated in PBS $\pm 5 \mathrm{mM} \mathrm{K}_{\mathrm{o}}$ (tetramethylammonium replacement) and cations measured as described in Methods and Table IV. Statistical comparisons ( $t$ test): $A$ vs. $B, P<0.001 ; B$ vs. $F, P$ $<0.028$.

no effect on cation content of normal cells after $18 \mathrm{~h}$ incubation under oxygenated or deoxygenated conditions (data not shown). Pharmacologic blockade of deoxy cation fluxes thus resulted in significant reduction of cation depletion of deoxygenated sickle cells in vitro. These data strongly implicate this cation transport pathway in the cation loss observed in deoxygenated sickle cells, and suggest that secondary effects of deoxygenation, such as intracellular osmotic changes or membrane "stretch" from tactoid formation, are not involved. The reduction of anion permeability by DIDS is not a likely explanation for the drug's effect on cation loss in deoxygenated sickle cells, because net chloride movements in DIDS-treated red cells remain very high relative to the cation movements involved in these experiments (30).

In summary, without sodium pump activity, deoxygenation was not sufficient to produce net cation loss in sickle cells; likewise, operation of the sodium pump under oxygenated conditions resulted in stable cation contents, and pharmacologic inhibition of deoxy cation fluxes reduced cation loss in deoxygenated sickle cells. These data strongly support the hypothesis that deoxy sodium and potassium fluxes and the sodium pump acting in concert effect cation depletion in sickle cells.

Cation depletion of xerocytes requires the sodium pump. Xerocytes are analogous to deoxygenated sickle cells in that they have an increased, but balanced leak of sodium and potassium. On the basis of the leak/pump hypothesis of dehydration, we would predict that these cells would become dehydrated in vitro, as long as the pumps were active. To test this prediction, we incubated xerocytes from two patients for $20 \mathrm{~h} \pm$ ouabain. Cation contents from these cells along with normal cells incubated under the same conditions are presented in Table VI. As in previous experiments, cation content of normal cells was stable over 20 $\mathrm{h}$ with or without ouabain. In contrast, xerocytes lost cellular cations under conditions where the sodium pump was active (no ouabain). It is interesting to note that in two previous studies
Table V. 18-h Incubation of Normal Cells

\begin{tabular}{ll}
\hline Condition & Percent change in total cations \\
\hline $\mathrm{A} \mathrm{O}_{2}$ & $-2.3 \pm 2.3$ \\
$\mathrm{~B} \mathrm{~N}_{2}$ & $-4.6 \pm 4.0$ \\
$\mathrm{C} \mathrm{O}_{2}+$ ouabain & $-1.2 \pm 2.6$ \\
$\mathrm{D} \mathrm{N}_{2}+$ ouabain & $-3.7 \pm 3.9$ \\
\hline
\end{tabular}

Cells were incubated as described in Table IV. Data are the means $( \pm S D)$ of cation changes for each condition in four experiments.

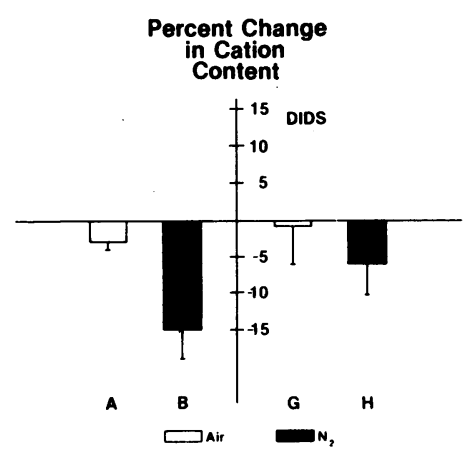

Figure 5. Cation changes in sickle cells incubated $18 \mathrm{~h}$ in PBS5K: effect of DIDS. Cells were pretreated with $10 \mu \mathrm{M}$ DIDS for $20 \mathrm{~min}$ at $37^{\circ} \mathrm{C}$, followed by three washes without drug; control cells were similarly preincubated without drug and washed. Samples were then resuspended for longterm incubation as described in Methods. 
Table VI. 20-h Incubation of Xerocytes

\begin{tabular}{|c|c|c|c|c|c|c|c|c|}
\hline & \multicolumn{8}{|c|}{ Cation content $(\mathrm{meq} / \mathrm{kg} \cdot \mathrm{Hb})$} \\
\hline & \multicolumn{3}{|l|}{ Initial } & \multirow[b]{2}{*}{ Ouabain } & \multicolumn{4}{|l|}{ Final } \\
\hline & $\mathrm{Na}$ & $\mathbf{K}$ & $(\mathrm{Na}+\mathrm{K})$ & & $\mathrm{Na}$ & $\mathbf{K}$ & $(\mathrm{Na}+\mathrm{K})$ & Percent change \\
\hline \multirow[t]{2}{*}{ A.C. } & 109 & 131 & 240 & - & 157 & 56.2 & 213 & -11.2 \\
\hline & & & & + & 281 & 18.9 & 300 & +25.0 \\
\hline \multirow[t]{2}{*}{ R.C. } & 116 & 135 & 251 & - & 164 & 62.6 & 227 & -9.6 \\
\hline & & & & + & 299 & 21.2 & 320 & +27.6 \\
\hline \multirow[t]{2}{*}{ Control } & 24.5 & 293 & 317 & - & 20.3 & 293 & 313 & -1.3 \\
\hline & & & & + & 61.2 & 257 & 318 & +0.3 \\
\hline
\end{tabular}

Cells were incubated at $37^{\circ} \mathrm{C}$ in GBS as described in Methods. Percent change compares final with initial $(\mathrm{Na}+\mathrm{K})$. Standard deviations of triplicate cation measurements ranged from 0.5 to $3 \%$.

of cation permeability in xerocytes, net cation loss (i.e., potassium loss in excess of sodium gain) was also seen in short-term incubations without ouabain $(4,5)$; with ouabain, sodium and potassium movements were equal (see Table I). In this study the presence of ouabain in long-term incubations resulted in sodium gain in excess of potassium loss. In these cells cation gradients had been dissipated by prolonged incubation with ouabain (cellular $\mathrm{Na}=140, \mathrm{~K}=10 \mathrm{mmol} /$ liter cells), and the gain of cations in explicable on the basis of the approach to Donnan equilibrium. However, from the short-term measurements, we know that passive sodium and potassium movements were balanced in xerocytes in which cation contents remained close to in vivo levels (Table I), indicating that passive cation permeability is not responsible for the cation depletion of xerocytes. Therefore, the predicted loss of cation after overnight incubation of xerocytes with active pumps supports the concept of the sodium pump's involvement in dehydration of cells with elevated but balanced cation leaks.

\section{Discussion}

This study has addressed the mechanism of dehydration in two pathologic red cells with different underlying defects. Xerocytic red cells have an elevated passive permeability to sodium and potassium, apparently as the result of a primary but as yet uncharacterized membrane defect. The data presented here, as well as that from the literature, show that the net sodium and potassium movements resulting from this defect are balanced. Similarly, in sickle red cells we and others (17) have demonstrated a balanced flux of sodium and potassium stimulated by deoxygenation. In both cell types we have shown that passive cation fluxes are balanced and therefore cannot be solely responsible for cation depletion. Our long-term incubation studies confirmed this finding, since ouabain-treated cells did not lose cations in vitro over an 18-h incubation. Only cells with active sodium pumps became cation depleted; in sickle cells this phenomenon required deoxygenation, reflecting the involvement of deoxy cation fluxes in the process. This cation pathway was further implicated by the reduction of cation depletion in cells pretreated with DIDS, which blocks deoxy cation fluxes (29). These data strongly support the hypothesis that the sodium pump is the primary agent of dehydration in cells with balanced cation leads, and in the case of sickle cells, that deoxy sodium and potassium fluxes constitute the contributory leak.
Much emphasis has been placed on the finding that the cellular influx and content of calcium are increased in sickle cells, especially in the deoxygenated state $(31,32)$. This phenomenon has stimulated speculation that calcium-activated potassium fluxes (i.e., the Gardos pathway) might mediate deoxy cation fluxes and/or cation depletion $(16,32)$. However, a growing body of data suggest that this is not the case for deoxy cation fluxes. The Gardos pathway is potassium selective (33), which is not consistent with the balanced sodium fluxes that we and others $(16,17)$ have shown accompany potassium fluxes stimulated by deoxygenation of sickle cells. Glader and Nathan showed no effect of calcium on changes in sodium and potassium contents in short-term incubations of deoxygenated sickle cells (16). Bookchin and Lew have shown that deoxy potassium influx could be separated from calcium uptake in heterozygous sickle cells (34).

The increased calcium influx induced by deoxygenation of sickle cells might transiently activate a Gardos potassium channel independent of the deoxy cation pathway, leading to small pulses of potassium efflux, which might be significant over long time periods in vivo. The elevated intracellular calcium levels in sickle cells, however, can be accounted for by calcium sequestered in endocytic vesicles, $(35,36)$, and ionized calcium concentrations measured by nuclear magnetic resonance techniques in sickle cells were found to be normal, even in deoxygenated cells (37). Any changes in cytoplasmic calcium concentration affecting cation permeability thus must be transient and/or localized within the cells. The calcium-dependent changes in cell density seen in deoxygenated sickle cells (38) support this hypothetical mechanism, although direct evidence for calcium activation of a potassium channel in sickle cells under physiologic conditions is not yet available. In the experiments presented here, cation loss from deoxygenated sickle cells was demonstrated in vitro in the absence of external calcium, suggesting that calcium is not required for cation depletion mediated by deoxy cation fluxes and the sodium pump.

Several reports have dealt with rapid changes in cell density upon deoxygenation of sickle cells. Fales (39) and Tosteson et al. (40) reported no change in sickle cell water content with deoxygenation, but their techniques were insensitive to the increase in water content in deoxygenated normal red cells reported by others (41). Masys et al. (42) used dilution of ${ }^{131} \mathrm{I}$-albumin to assay water movement and found an apparent reduction in sickle cell water content after deoxygenation, although no as- 
sessment was made of binding of ${ }^{131} \mathrm{I}$-albumin to cells. Fabry and Nagel (41) examined cell density changes with deoxygenation using Percoll-Stractan gradients. Normal cells became less dense upon deoxygenation. The behavior of sickled cells depended on pH and the morphologic characteristics of the sickle cells tested: Irreversibly sickled cells always became denser, while reversibly sickled cells remained unchanged at $\mathrm{pH} 7.4$, but became more dense below pH 7.25. The mechanism of these changes in density was not elucidated, but alteration of cellular cations is unlikely, because of the rapidity of the density changes.

Changes in the osmotic behavior or net charge of hemoglobin $S$ upon deoxygenation might produce the acute density changes observed by Fabry and Nagel, although no direct experimental data supports the occurrence of such behavior of hemoglobin. A change in the net charge of hemoglobin (or other impermeant anion) could acutely alter chloride content, and therefore intracellular $\mathrm{pH}$ and membrane potential. Only if the cell were able to respond to the change in membrane potential or internal $\mathrm{pH}$ by altering membrane permeability to cations would cation content change. In red cells homozygous for hemoglobin $\mathrm{C}$, but not in normal red cells, cation permeability regulation appears to occur in response to intracellular $\mathrm{pH}$ : potassium permeability increases as internal pH decreases (43). A similar pathway was recently reported in oxygenated sickle cells (44). It should be pointed out, however, that the acute density changes in deoxygenated sickle cells seen by Fabry and colleagues and the changes in cation content seen upon long-term incubation in this study are not both explicable in terms of hemoglobin charge effects. An increase in hemoglobin electronegativity secondary to deoxygenation would tend to shrink cells acutely (cause chloride to leave) and would result in hyperpolarization of the membrane. Any regulatory activity on the part of the cell to restore membrane potential (and cellular $\mathrm{pH}$ ) toward normal would involve the uptake, not loss, of cation. In addition the reduction in cation loss seen in deoxygenated sickle cells pretreated with DIDS supports the direct involvement of deoxy cation fluxes in the process of cation depletion, and argues against indirect effects on cation content secondary to changes in hemoglobin charge. Furthermore, the volume-regulatory pathways seen in nucleated red cells (45), sickle and hemoglobin C cells $(43,44)$, are ouabain insensitive, and are present in oxygenated cells, which is inconsistent with our findings that cation loss in sickle cells depends on both deoxygenation and sodium pump activity.

The volume regulatory pathway described by Brugnara and colleagues does represent a potential mechanism of cation loss in pathologic red cells $(43,44)$, independent of hemoglobin charge effects and deoxygenation. The volume-sensitive pathway in sickle cells has higher activity in the lightest population of sickle cells, even when cation contents and volumes of the density fractions are equalized by nystatin treatment (44). Canessa has shown that a $\mathrm{K}-\mathrm{Cl}$ cotransport pathway exists in normal reticulocytes that is qualitatively and quantitatively similar to the volume-sensitive potassium pathway in sickle cells (46). More research is needed to determine if this pathway is specific for the sickle mutation and whether it contributes in vivo to cation loss in sickle cells. In any case, this ouabain-insensitive system would be independent of the interaction between deoxy cation fluxes and the sodium pump.

The concept of the pump's involvement in cation depletion in pathologic red cells was first touched on by Glader and Nathan, who pointed out that a cell with a selective potassium leak would not be able to compensate for potassium loss by increasing pump activity (16). Clark et al. demonstrated the dehydrating capacity of the sodium pump in normal cells and suggested that cation depletion resulting from excessive potassium loss in deoxygenated sickle cells might be exacerabated by pump activity in response to deoxy sodium influx $(19,20)$. Indirect support for this concept comes from the recent report of Izuma et al., who showed ouabain-sensitive changes in MCHC in deoxygenated sickle cells (28). Our data provide evidence that the sodium pump is, in fact, a primary agent of cation depletion in both sickle cells and xerocytes. In xerocytic red cells, the process of cation loss is continuous because the balanced cation leaks provide a constant stimulus to the sodium pump, the compensatory effort of which is unbalanced. The sickle cells in our experiments had elevated sodium and potassium permeability resulting from deoxygenation. The experiment conditions employed did not allow for more physiologic conditions of cyclical oxygenation and deoxygenation. Nevertheless, given the reversibility of deoxy cation fluxes and their activation in vitro at physiologic venous oxygen tensions $(40,47)$, it is reasonable to postulate that transient elevations of cation permeability occur in sickle cells in vivo, leading to elevations in sodium concentrations. Responding to elevated cellular sodium, the pump is stimulated, returning sodium concentration toward its baseline upon reoxygenation. There is experimental evidence that ouabain-sensitive potassium influx is, in fact, increased during deoxygenation of sickle cells in vitro, presumably as a result of increased cellular sodium (28). However, because of pump stoichiometry (48) and the fact that regulation of pump rate is primarily via intracellular sodium (not potassium) concentration (49), pump compensation for balanced deoxy cation leaks ceases before potassium levels return to normal. Each period of deoxygenation, however short, thus would lead to an incremental reduction in cellular cations.

Xerocytes and deoxygenated sickle cells lost $\sim 10 \%$ of their cellular cations during $18-20 \mathrm{~h}$ incubation in vitro. These changes, although somewhat small experimentally, are of the order of magnitude expected from the biologic behavior of these cells. A cell that loses $10 \%$ of its cation per day, would lose about $40 \%$ in $5 \mathrm{~d}$. Although no data are available to establish the level of dehydration required to trigger red cell destruction in vivo, this time frame of cation depletion is consistent with an estimated half life $\left({ }^{51} \mathrm{Cr}\right)$ for xerocytes of 4-15 $d(4,50)$ and for sickle cells of 7-13 d (51). Such quantitative extrapolations with sickle cells are complicated by the fact deoxy fluxes are intermittent in vivo and their magnitude under such circumstance is unknown. The rate of deoxy cation flux has been shown furthermore to be influenced by the number of alpha-globin genes (18) and possibly the content of fetal hemoglobin (52). There is also evidence that for a given patient, heterogeneity exists among various cell populations as to the rate of cellular dehydration $(53,54)$. Maximal sodium pump rates may also vary among certain density fractions of sickle cells (19). Many factors thus may modulate the rate at which cation depletion results from the interaction of the sodium pump and deoxy cation fluxes in vivo. Regardless of the pace of the process, every incremental drop in water content would increase the cell's rigidity and its tendency to sickle, hastening its destruction.

One of the important features of this model of cation depletion of sickle cells is the fact that its major components, the sodium pump and deoxy cation fluxes, are active under physiologic conditions of intra- and extracellular ionic composition, pH, cellular metabolic state, and oxygen tension. Deoxy cation fluxes are optimal at $\mathrm{pH} 7.4-7.5(47,55)$ and are activated in 
the $\mathrm{PO}_{2}$ range of 30 to 40 torr (47). Extremes of $\mathrm{pH}$, circulatory sequestration, cytoplasmic calcium accumulation, or ATP exhaustion thus would not be necessary for cation depletion in sickle cells.

We have shown that the mechanism of cation depletion is similar in sickle cells and hereditary xerocytic red cells, two pathologic cell types with different underlying defects. The fundamental features of the model are increased cation permeability with balanced net sodium and potassium movements and compensatory activity of the sodium pump, presumably with $3 \mathrm{Na}_{\text {out }}$ : $2 \mathrm{~K}_{\text {in }}$ stoichiometry. We propose that this mechanism can be generalized to apply to any cell with pathologic leaks. As long as the ratio of passive cation movements is not appropriate for the coupling ratio of the sodium pump, an imbalance in total cation fluxes will occur, leading to a change in cation content with time. In addition to the potential variables of passive cation permeability and pump coupling, abnormalities of the sodium potassium cotransport pathway might effect net cation movement. Regardless of the possible permutations involved, the basic concept is that abnormal cation leaks may interact with the other transport pathways in the cell to produce net changes in cation content. Any evaluation of cells with manifestations of altered volume control mechanisms must take into account this general principle.

\section{Acknowledgments}

We are indebted to Arlene Dew for excellent technical assistance and to Lindle Leask and Marsha Sumner for preparation of the manuscript.

This work was supported by National Institutes of Health grants HL32805 and 5P60-HL15157.

\section{References}

1. Rodgers, G. P., A. N. Schechter, and C. T. Noguchi. 1985. Cell heterogeneity in sickle cell disease. Quantitation of the erythrocyte density profile. J. Lab. Clin. Med. 106:30-37.

2. Fabry, M. E., and R. L. Nagel. 1982. Heterogeneity of red cells in the sickler: A characteristic with practical and pathological implications. Blood Cells. 8:9-15.

3. Clark, M. R., N. Mohandas, V. Caggiano, and S. B. Shohet. 1978. Effects of abnormal cation transport on deformability of desiccytes. $J$. Supramol. Struct. 8:521-532.

4. Platt, O. S., S. E. Lux, and D. G. Nathan. 1981. Exercise-induced hemolysis in xerocytosis. Erythrocyte dehydration and shear sensitivity. J. Clin. Invest. 68:631-638.

5. Glader, B. E., N. Fortier, M. M. Albala, and D. G. Nathan. 1974. Congenital hemolytic anemia associated with dehydrated erythrocytes and increased potassium loss. N. Engl. J. Med. 291:491-496.

6. Wiley, J. J., J. C. Ellory, M. A. Shuman, C. C. Sholler, and R. A. Cooper. 1975. Characteristics of the membrane defect in hereditary stomatocytosis syndrome. Blood. 46:337-356.

7. LaCelle, P. L., and R. I. Weed. 1971. The contribution of normal and pathologic erythrocytes to blood rheology. Prog. Hematol. 7:1-33.

8. Clark, M. R., N. Mohandas, and S. B. Shohet. 1982. Hydration of sickle cells using the sodium ionophore monensin. J. Clin. Invest. 70: 1074-1080.

9. Clark, M. R., N. Mohandas, and S. B. Shohet. 1980. Deformability of oxygenated irreversibly sickled cells. J. Clin. Invest. 65:189-196.

10. Platt, O. S. 1982. Exercise-induced hemolysis in sickle cell anemia. Shear sensitivity and erythrocyte dehydration. Blood. 59:1055-1060.

11. Kaul, D. K., M. E. Fabry, P. Windish, S. Baez, and R. L. Nagel. 1983. Erythrocytes in sickle cell anemia are heterogeneous in their rheological and hemodynamic characteristics. J. Clin. Invest. 72:22-31.
12. Coletta, M., J. Hofrichter, F. A. Ferrone, and W. A. Eaton. 1982. Kinetics of haemoglobin polymerization in sigle red cells. Nature (Lond.). 300:194-197.

13. Bookchin, R. M., T. Balaz, and L. C. Landau. 1976. Determinants of red cell sickling. Effects of varying $\mathrm{pH}$ and of increasing intracellular hemoglobin concentration by osmotic shrinkage. J. Lab. Clin. Med. 87: 597-616.

14. Hofrichter, J., P. D. Ross, and W. A. Eaton. 1976. Supersaturation in sickle cell hemoglobin solutions. Proc. Natl. Acad. Sci. 73:3035-3039.

15. Tosteson, D. C., E. Carlsen, and E. T. Dunham. 1955. The effects of sickling on ion transport. I. Effect of sickling on potassium transport. J. Gen. Physiol. 39:31-53.

16. Glader, B. E., and D. G. Nathan. 1978. Cation permeability alterations during sickling. Relationship to cation composition and cellular hydration of irreversibly sickled cells. Blood. 51:983-989.

17. Berkowitz, L. R., and E. P. Orringer. 1985. Passive sodium and potassium movements in sickle erythrocytes. Am. J. Physiol. 249:C208C214.

18. Embury, S. H., K. Backer, and B. E. Glader. 1985. Monovalent cation changes in sickle erythrocytes: A direct reflection of $\alpha$-globin gene number. J. Lab. Clin. Med. 106:75-79.

19. Clark, M. R., C. E. Morrison, and S. B. Shohet. 1979. Monovalent cation transport in irreversibly sickled cells. J. Clin. Invest. 62:329-337.

20. Clark, M. R., J. C. Guatelli, A. T. White, and S. B. Shohet. 1981. Study of the dehydrating effect of the red cell $\mathrm{Na}^{+} / \mathrm{K}^{+}$pump in nystatintreated cells with varying $\mathrm{Na}^{+}$and water content. Biochim. Biophys. Acta. 646:422-432.

21. Danon, D., and Y. Marikovsky. 1964. Determination of density distribution of red cell populations. J. Lab. Clin. Med. 64:668-676.

22. Joiner, C. H., and P. K. Lauf. 1978. Modulation of ouabain binding and potassium pump fluxes by cellular sodium and potassium in human and sheep erythrocytes. J. Physiol. (Lond.). 283:177-196.

23. Joiner, C. H., and P. K. Lauf. 1975. The effect of anti-L on ouabain binding in sheep erythrocytes. J. Membr. Biol. 21:99-112.

24. Garay, R., N. Adragna, M. Canessa, and D. C. Tosteson. 1981. Outward sodium and potassium cotransport in human red cells. $J$. Membr. Biol. 62:169-174.

25. Wiley, J. S. 1972. Coordinated increase of sodium leak and sodium pump in hereditary spherocytosis. Br. J. Haematol. 22:529-536.

26. Wiley, J. S., and C. C. Shaller. 1977. Selective loss of calcium permeability on maturation of retriculocytes. J. Clin. Invest. 59:11131119.

27. Chailley, B., C. Feo, R. Garay, G. Dagher, R. Bruckdorfer, S. Fischer, J. P. Piau, and J. Delannay. 1981. Evidence for imbalanced furosemide-sensitive $\mathrm{Na}^{+}, \mathrm{K}^{+}$cotransport in hereditary stomatocytosis. Scand. J. Haematol. 27:365-373.

28. Izumo, H., M. Williams, R. Rosa, J. Flier, and F. H. Epstein. 1985. $\mathrm{Na} / \mathrm{K}$ ATPase and ion fluxes in sickle cell anemia. Implications for therapy. Clin. Res. 33:343. (Abstr.)

29. Joiner, C. H., and A. Dew. 1986. Deoxy cation fluxes in sickle cells are inhibited by DIDS. Fed. Proc. 45:446. (Abstr.)

30. Froehlich, O., C. Liebson, and R. B. Gunn. 1983. Chloride net efflux from intact erythrocytes under slippage condition. J. Gen. Physiol. 81:127-152.

31. Palek, J. 1977. Red cell calcium content and transmembrane calcium movements in sickle cell anemia. J. Lab. Clin. Med. 89:15651372.

32. Eaton, J. W., H. S. Jacobs, and J. G. White. 1979. Membrane abnormalities of irreversibly sickled cells. Semin. Hematol. 16:52-64.

33. Blum, R. M., and J. F. Hoffman. 1971. The membrane locus of Ca-stimulated $\mathrm{K}$ transport in energy depleted human red blood cells. $J$. Membr. Biol. 6:315-328.

34. Bookchin, R. M., and V. L. Lew. 1981. Effect of a "sickling pulse" on calcium and potassium transport in sickle cell trait red cells. J. Physiol. (Lond.). 212:265-280.

35. Lew, V. L., A. Hockaday, M. Sepulveda, A. P. Somlyo, A. V. Somlyo, O. E. Ortiz, and R. M. Bookchin. 1986. Compartmentalization 
of sickle cell calcium in endocytic inside-out vesicles. Nature (Lond.). 315:586-589.

36. Rubin, E., R. A. Schlegel, and P. Williamson. 1986. Endocytosis in sickle erythrocytes: a mechanism for elevated intracellular $\mathrm{Ca}^{2+}$ levels. J. Cell. Physiol. 126:53-59.

37. Berkowitz, L., E. Orringer, R. London, and L. Levy. 1985. Regulation of ionized calcium in sickle RBC. Blood. 66:63a. (Abstr.)

38. Bookchin, R. M., O. E. Ortiz, and V. L. Lew. 1985. Cell dehydration from sickling-induced calcium sensitive $\mathrm{K}^{+}$channel activation. Blood. 66:56a. (Abstr.)

39. Fales, F. W. 1978. Water distribution in blood during sickling of erythrocytes. Blood. 51:703-889.

40. Tosteson, D. C., E. Shea, and R. C. Darling. 1952. Potassium and sodium of red blood cells in sickle cell anemia. J. Clin. Invest. 31: 406-411.

41. Fabry, M. E., and R. L. Nagel. 1982. The effect of deoxygenation on red cell density: Significance for the pathophysiology of sickle cell anemia. Blood. 60:1370-1377.

42. Masys, D. R., P. A. Bromberg, and S. P. Balcerzak. 1974. Red cells shrink during sickling. Blood. 44:885-889.

43. Brugnara, C., A. S. Kopin, F. H. Bunn, and D. C. Tosteson. 1985. Regulation of cation content and cell volume in erythrocytes from patients with homozygous hemoglobin C disease. J. Clin. Invest. 75: 1608-1617.

44. Brugnara, C., H. F. Bunn, and D. C. Tosteson. 1986. Regulation of erythrocyte cation and water content in sickle cell anemia. Science (Wash. DC). 232:288-390.

45. Kregenow, F. M. 1981. Osmoregulatory salt transporting mechanisms. Control of cell volume in anisotonic media. Am. Rev. Physiol. 43:493-305.
46. Canessa, M. 1986. Volume regulating $\mathrm{K}^{+} \mathrm{Cl}^{-}$transporter in sickle cell disease. In Pathophysiologic Aspects of Sickle Cell Vaso-occlusion, R. L. Nagel, editor, Alan R. Liss, Inc., New York. In press.

47. Joiner, C. H. 1985. Physiologic characteristics of sodium and potassium fluxes stimulated by deoxygenation of sickle red cells. Pediatr. Res. 19:263a. (Abstr.)

48. Garrahan, P. J., and I. M. Glynn. 1967. The stoichiometry of the sodium pump. J. Physiol. (Lond.). 192:217-235.

49. Garay, R. P., and P. J. Garrahan. 1973. The interaction of sodium and potassium with the sodium pump in red cells. J. Physiol. (Lond.). 231:297-325.

50. Miller, D. R., F. R. Rickles, M. A. Lichtman, P. L. LaCelle, J. Bates, and R. I. Weed. 1971. A new varient of hereditary hemolytic anemia with stomatocytosis and erythrocyte cation abnormality. Blood. 38:184-204.

51. McCurdy, P. R., and A. S. Sherman. 1978. Irreversibly sickled cells and red cell survival in sickle cell anemia: A study with both $D F^{32} \mathrm{P}$ and ${ }^{51} \mathrm{Cr}$. Am. J. Med. 64:253-258.

52. Fabry, M. E., I. D. Buchannan, and R. L. Nagel. 1984. Red cell density and rate of potassium loss are affected by hemoglobin $F$ levels in sickle cell anemia. Clin. Res. 32:551a. (Abstr.)

53. Bertles, J., and P. Milner. 1968. Irreversibly sickled erythrocytes: Consequence of the heterogeneous distribution of the hemoglobin types in sickle cell anemia. J. Clin. Invest. 47:1731-1738.

54. Noguchi, C. T., G. J. Dover, G. P. Rodgers, G. R. Sergeant, S. E. Antonarakis, N. P. Anagnov, D. R. Higgs, D. J. Weatherall, and A. N. Schechter. 1985. Alpha-thalassemia changes erythrocyte heterogeneity in sickle cell disease. J. Clin. Invest. 75:1632-1637.

55. Roth, E. F., Jr., R. L. Nagel, and R. M. Bookchin. 1981. pH dependency of potassium efflux from sickle cells. Am. J. Hematol. 11: 19-27. 